\title{
Shaping up the Future Spatial Plans for Urban Areas in Pakistan
}

\author{
Muhammad Qadeer ul Hussnain ${ }^{1, * \mathbb{D}}$, Abdul Waheed ${ }^{1}$, Khydija Wakil ${ }^{1}$, \\ Christopher James Pettit ${ }^{2}{ }^{\mathbb{D}}$, Ejaz Hussain ${ }^{3}$, Malik Asghar Naeem ${ }^{1}$ and Ghulam Abbas Anjum ${ }^{4}$ \\ 1 Department of Urban \& Regional Planning, National University of Science \& Technology (NUST), \\ Islamabad 44000, Pakistan; waheedabdul@nit.nust.edu.pk (A.W.); \\ khydijawakeel.urp@nit.nust.edu.pk (K.W.); asghar.naeem@nit.nust.edu.pk (M.A.N.) \\ 2 City Futures Research Centre, Built Environment, University of New South Wales, Sydney, NSW 2052, \\ Australia; c.pettit@unsw.edu.au \\ 3 Institute of Geographical Information Systems, National University of Science \& Technology (NUST), \\ Islamabad 44000, Pakistan; ejaz@igis.nust.edu.pk \\ 4 Department of City \& Regional Planning, University of Engineering \& Technology (UET), Lahore 54890, \\ Pakistan; gaanjum13@hotmail.com \\ * Correspondence: plannerqadeer.urp@nit.nust.edu.pk; Tel.: +92-334-9669884
}

Received: 8 April 2020; Accepted: 9 May 2020; Published: 21 May 2020

check for updates

\begin{abstract}
Since 2007, more than fifty percent of our planet's population is living in urban areas. In the coming decade, the rate of urbanization will be fastest in Asia and Africa. Within South Asian countries, urbanization has attained its fastest pace in Pakistan. Urban planners and agencies in Pakistan have tried various spatial plan making solutions to manage urban areas, but none have given the desired results. After a $20 \%$ increase in declared urban areas within last two decades, urban planners and policy makers are looking for a more innovative and realistic spatial planning solution, which could adjust to the uncertainties and complexities of real world. This research uses a mixed method approach comprising a two phased survey of professional planners, analyzed through the selective lexicon approach to document planners' opinions about the reasons behind the poor performance and conformance of spatial plans. This study documents the planners' understanding of the contemporary concept of 'scenario planning'. To explore the solution, this paper presents a semi-systematic review of the literature on the application of the 'scenario method in urban spatial planning'. As a result of this research, a comprehensive digital inventory of all spatial plans ever made in Pakistan has been developed. It has been found that $83 \%$ of the urban settlements in Pakistan are growing without a spatial plan and require immediate attention. Furthermore, in terms of the plan making process, twenty-seven major factors contributing to the failure of past plans have been identified and categorized under seven distinct plan making stages. Finally, a new process of spatial plan-making has been proposed, which is the fusion of scenario planning and the traditional plan-making process, backed by digital planning tools. In an era of smart cities and digitization, it is expected that the advancements in scenarios planning, coupled with a new data portal, will assist in addressing the implementation gap in practice, and result in more comprehensive data-driven spatial plans.
\end{abstract}

Keywords: urban plans; spatial plans; scenario planning; digital planning tools; planning support systems

\section{Introduction}

In our already urbanized planet, the major chunk of future urbanization will be concentrated in Asia and Africa [1,2]. Countries employ different policy instruments to manage spatial growth in 
urban areas. At local tiers, development control agencies are generally responsible for handling the growing urbanization by making and implementing urban spatial plans under different names and scope in different parts of the world, and there is an active debate on what works well, where and why [3-7]. The contemporary form of spatial plan making involves the use of 'scenarios' and 'digital planning tools' as a means to ensure a more intuitive and futuristic approach to spatial plan making, which could better handle the uncertainties and complexities of the real world, along with the true engagement of stakeholders, their roles and contributions [8-10].

Within South Asian countries, in Pakistan, the urban population has increased three-fold in past 30 years, and it is expected that the country will become predominately urban by 2025 [11,12]. Resultantly, the number of urban areas has increased from 468 in 1998 to 624 in 2017 (33\%) [13,14]. In the case of Pakistan, government agencies have tried various planning approaches and plan-making solutions to handle urban growth over time [15]. For instance, from 1960 to 1980, the planning practice was more focused on detailed land-use planning, which resulted in Master Plans, Landuse Plans and Zoning Plans. Later, the focus shifted to the long-range policy-oriented documents, which resulted in Outline Development Plans and Structure Plans from 1980 to 2000. In 2001, the urban plans were labeled as Spatial plan. However, after the implementation of Landuse Rules 2009, Peri-urban plans and Landuse Classification/Reclassification plans are in practice [16]. With the recent focus of the government on urban planning (the launch of five million housing programs and establishment of Naya Pakistan Housing Authority), the concept of master plans has attained public recognition once again. In the last quarter of 2019, a series of seminars took place on the themes of 'reimagining cities', 'rethinking master plans' and 'revitalizing urban planning'. However, no clear direction have been attained. The questions about the shape, contents and preparation methodology of a spatial planning document, which could adequately address the urbanization pressure, still prevail.

Since most of the past urban spatial plans have not been able to achieve their objectives, the quality of the plans along with their implementation status has been heavily critiqued in academic evaluations [17-19]. Researchers have highlighted that the main causes behind the failure of plans include the lack of ownership by stakeholders, inadequate participation, faulty projections and forecasts, overemphasis on data collection, absence of monitoring and evaluation mechanisms, lack of financial and legal backing $[15,18,20,21]$. Above all, the changes in real-world and urban growth have been so uncertain that most of the plans could not keep pace with the complex ground realities, and had to be abandoned.

This study endeavors to achieve three main objectives: (a) to produce the previously missing national dataset on declared urban areas viz-a-viz spatial plans, (b) to document the factors contributing to the failure of past spatial plans and (c) to present a novel 'scenario planning based' framework for future spatial planning in the declared urban areas.

\section{Literature Review}

\subsection{State of the Documentation of Urban Areas}

The facts on global and national urbanization are straightforward but alarming as they are reported by the United Nations and the World Bank. There are global efforts to define and document urban areas [2,22,23], along with country specific databases and mechanisms [24-27]. However, Pakistan's national response to defining and/or handling urban phenomena is vague. In contrast to global best practices, Pakistan has always struggled to identify and declare urban areas across census. The earlier censuses of 1951 and 1961 defined urban areas based on their administrative setup, nature of their activity and urban characteristics. However, it was changed in 1981, where the definition was limited to the administrative setup criteria only. The same definition was followed in 1998 as well. Resultantly, many places which were previously declared as 'urban' were no longer 'urban' after 1981 [28-30]. Arif highlights that 72 urban places in the 1972 census with a population of over one million were declared rural in 1981 . This resulted in a shift of $5.7 \%$ of the urban population to the rural $[14,28]$. 
Due to such definitional challenges and data abnormalities, none of Pakistan's cities were selected to be part of the global urban atlas [31]. The absence of standardized national level gazetteers for urban areas poses a new challenge in the temporal mapping of urban areas, making it land-use to explore the actual trend of urban centers increase in various regions.

Like many other developing countries, Pakistan faces the issue of data deficiency in urban statistics. Unfortunately, even the Bureau of Statistics does not provide a publicly available list of declared urban areas. Regarding the mapping of urban areas, two efforts are particularly important to highlight. The first one is the Global Human Settlements Urban Centre Database (GHS-UCDB), which has identified 301 settlements as 'Urban' from all over Pakistan. Despite its excellent global methodology, this does not cover the full picture of Pakistan. Another effort is at a sub-national level, which has appeared in the form of the Punjab Cities Growth Atlas, covering 194 cities of Punjab (the most populous province of Pakistan), and presents their expansion till 2015 [32]. However, both studies are not sufficient to cover the full spectrum of urban areas inventory in Pakistan. This reflects the need for the mapping of the declared urban settlements over time, and making it available in the geospatial format.

\subsection{Evolution of Scenario Planning in Global Context}

As the uncertainty increased in the real world and forecasts started going wrong, the concept of 'scenario planning' has started gaining the attention of the urban planners. The term 'scenario', after being introduced by Kahn in 1960s as "hypothetical sequences of events constructed for the purpose of focusing attention on causal processes and decision-points", was defined from various angles by other scholars [33]. In its very essence, a scenario is a structured representation of a probable future that narrates how the future might unfold if a series of events take place along a time scale. From the land-use planning perspective, a scenario represents the landuse pattern of a given space that would appear if a certain set of plans, policies and regulations are implemented during a period of time [34].

In the last sixty years, a lot has been written on 'scenarios', their components, building techniques and scenario planning approaches. In the current body of knowledge, work on terminologies, theory and concepts has been done by Schoemaker, Godet, Myers, Hopkins, Susan, Honton and others [35-41]. Another group has explored the applications of the scenario method in various fields, including urban planning [10,34,42,43], transport planning [44-47]. Similarly, research has been done in exploring the ways on how scenario planning can be welcomed and integrated in the planning process $[34,35,43,48-50]$. Furthermore, another group has documented the scenario planning applications in real life or lab-based projects [50-52]. In addition to that, a group has been working on the development and documentation of digital planning tools and planning support systems to ease such scenario planning integration in urban planning.

Building upon the work of Clark [34], Table 1 exclusively enlists studies and project reports that demonstrate the application of the scenario planning approach in urban planning projects.

Table 1. Year-wise list of studies and projects indicating the application of the 'scenario method' in urban planning.

\begin{tabular}{cclcc}
\hline Sr. & Year & \multicolumn{1}{c}{ Study/Project } & Country & Reference \\
\hline 1 & 1964,1992 & $\begin{array}{l}\text { Regional growth study of the Green Spring and } \\
\text { Worthington Valleys of Baltimore County, } \\
\text { Maryland }\end{array}$ & USA & $\begin{array}{c}\text { (McHarg, 1992, pages 79-93; } \\
\text { Wallace-McHarg Associates, } \\
\text { 1964) }\end{array}$ \\
\hline 2 & 1966 & $\begin{array}{l}\text { An urban development study of the Detroit } \\
\text { area }\end{array}$ & USA & $\begin{array}{c}\text { (Doxiadis, 1966; 1967; 1970; } \\
\text { Schneider, 1972) }\end{array}$ \\
\hline 3 & 1975 & $\begin{array}{l}\text { A study of energy consumption, land-use, and } \\
\text { growth policy for metropolitan Washington, } \\
\text { DC }\end{array}$ & USA & (Roberts, 1975) \\
\hline
\end{tabular}


Table 1. Cont.

\begin{tabular}{|c|c|c|c|c|}
\hline Sr. & Year & Study/Project & Country & Reference \\
\hline 4 & 1977 & $\begin{array}{l}\text { An urban sprawl impact study for the town of } \\
\text { Burlington, Massachusetts }\end{array}$ & USA & (Fabos and Caswell, 1977) \\
\hline 5 & 1978 & $\begin{array}{l}\text { The METLAND comprehensive regional } \\
\text { land-use planning methods }\end{array}$ & USA & (Fabos, et al., 1978) \\
\hline 6 & 1984 & $\begin{array}{l}\text { A resource accountability assessment for the } \\
\text { town of Greenfield, Massachusetts }\end{array}$ & USA & (Gross and Fabos, 1984) \\
\hline 7 & 1991 & $\begin{array}{l}\text { An urban development policy assessment for } \\
\text { the City of Vasteras, Sweden }\end{array}$ & Sweden & (Khakee, 1991) \\
\hline 8 & 1993 & $\begin{array}{l}\text { The alternative urban futures study for the } \\
\text { greater San Francisco Bay region, California }\end{array}$ & USA & (Landis et al., 1993) \\
\hline 9 & 1996 & The New York Regional Plan & USA & (Yaro and Hiss, 1996), \\
\hline 10 & 1996 & $\begin{array}{l}\text { The American Planning Association's } \\
\text { guidebook for sustainable development }\end{array}$ & USA & (APA, 1996) \\
\hline 11 & 1998 & $\begin{array}{l}\text { The New Jersey long-range statewide } \\
\text { transportation plan study }\end{array}$ & USA & $\begin{array}{l}\text { Bonnett and Olson, 1998, } \\
\text { pages 313-320) }\end{array}$ \\
\hline 12 & 1998 & $\begin{array}{l}\text { Three Scenarios for Land-Use Change: A Case } \\
\text { Study in Central Europe }\end{array}$ & Austria & $\begin{array}{l}\text { (Prieler, Leskó, and } \\
\text { Anderberg 1998) [53] }\end{array}$ \\
\hline 13 & 2000 & $\begin{array}{l}\text { Towards Incorporating Dynamic Consequences } \\
\text { into Regional Planning Scenarios }\end{array}$ & Australia & (C Pettit and Pullar 2000) \\
\hline 14 & 2001 & $\begin{array}{l}\text { An urban land-development study of the Santa } \\
\text { Barbara region, California }\end{array}$ & USA & (UCIME, 2001), \\
\hline 15 & 2001 & $\begin{array}{l}\text { A scenario analysis of China's landuse and } \\
\text { land-cover change }\end{array}$ & China & (Hubacek and Sun 2001) [55] \\
\hline 16 & 2001 & $\begin{array}{l}\text { Planning Scenarios for the Growth of Hervey } \\
\text { Bay }\end{array}$ & Australia & $\begin{array}{l}\text { (Christopher Pettit and } \\
\text { Pullar 2001) [56] }\end{array}$ \\
\hline 17 & 2001 & $\begin{array}{l}\text { Formulation an On-line Spatial Decision } \\
\text { Support System for Evaluating urban and } \\
\text { Regional Planning Scenarios }\end{array}$ & Australia & $\begin{array}{l}\text { (Christopher Pettit, Shyy, } \\
\text { and Stimson 2003) [57] }\end{array}$ \\
\hline 18 & 2002 & $\begin{array}{l}\text { The Cambridge Futures study for the City of } \\
\text { Cambridge, England }\end{array}$ & USA & $\begin{array}{l}\text { Echenique, 1999; Roberts, } \\
2002\end{array}$ \\
\hline 19 & 2002 & $\begin{array}{l}\text { Formulating a Sustainable Development Land } \\
\text { Use Scenario Using GIS }\end{array}$ & Australia & $\begin{array}{l}\text { (Christopher James Pettit } \\
\text { 2002) [58] }\end{array}$ \\
\hline 20 & 2002 & $\begin{array}{l}\text { An Integrated Multi-Scaled Decision Support } \\
\text { Framework used in the Formulation and } \\
\text { Evaluation of Land-Use Planning Scenarios for } \\
\text { the Growth of Hervey Bay }\end{array}$ & Australia & (Pettit 2002) [59] \\
\hline 21 & 2003 & The Use of Scenarios in Land-Use Planning & USA & (Xiang and Clarke 2003) [34] \\
\hline 22 & 2004 & $\begin{array}{l}\text { A way forward for land-use planning to } \\
\text { achieve policy goals by using spatial modelling } \\
\text { scenarios }\end{array}$ & Australia & $\begin{array}{l}\text { (Christopher Pettit and } \\
\text { Pullar 2004) [60] }\end{array}$ \\
\hline 23 & 2006 & $\begin{array}{l}\text { Scenario based spatial modelling for landuse } \\
\text { planning and evaluation }\end{array}$ & Malaysia & $\begin{array}{l}\text { (Nazri, Ludin, and Yaakup } \\
\text { 2006) [61] }\end{array}$ \\
\hline 24 & 2007 & $\begin{array}{l}\text { Participatory scenario analysis for integrated } \\
\text { regional modelling }\end{array}$ & Switzerland & (Walz et al. 2007) [62] \\
\hline 25 & 2007 & $\begin{array}{l}\text { Participatory scenario construction in land use } \\
\text { analysis: An insight into the experiences } \\
\text { created by stakeholder involvement in the } \\
\text { Northern Mediterranean }\end{array}$ & EU & $\begin{array}{l}\text { (Patel, Kok, and Rothman } \\
\text { 2007) [63] }\end{array}$ \\
\hline
\end{tabular}


Table 1. Cont.

\begin{tabular}{|c|c|c|c|c|}
\hline Sr. & Year & Study/Project & Country & Reference \\
\hline 26 & 2008 & $\begin{array}{l}\text { Your Vision or My Model? Lessons from } \\
\text { Participatory Land Use Scenario Development } \\
\text { on a European Scale }\end{array}$ & EU & (Volkery et al. 2008) [64] \\
\hline 27 & 2009 & $\begin{array}{l}\text { A Planning Support System Toolkit Approach } \\
\text { for Formulating and Evaluating Land-use } \\
\text { Change Scenarios }\end{array}$ & Australia & $\begin{array}{l}\text { (Christopher James Pettit } \\
\text { and Wyatt 2009) [65] }\end{array}$ \\
\hline 28 & 2009 & $\begin{array}{l}\text { Visualising What If? generated land use } \\
\text { planning scenarios }\end{array}$ & Australia & (Bishop et al. 2009) [66] \\
\hline 29 & 2010 & $\begin{array}{l}\text { Developing a scenario development approach } \\
\text { and the alternate landuse scenarios }\end{array}$ & Indonesia & (Vitriani 2010) [67] \\
\hline 30 & 2013 & $\begin{array}{l}\text { Scenario Planning Guidelines for developing } \\
\text { and evaluating alternative land-use and } \\
\text { transportation scenarios, Utha, Missoula, } \\
\text { Portland, Albany, Michigan, California }\end{array}$ & USA & (Lazarean 2013) [68] \\
\hline 31 & 2014 & The scenario method in urban planning & Serbia & $\begin{array}{l}\text { (Stojanovic, Mitkovic, and } \\
\text { Mitkovic 2014) [43] }\end{array}$ \\
\hline 32 & 2015 & Scenario Planning Course Development Guide & USA & (Goodspeed 2015) [69] \\
\hline 33 & 2015 & $\begin{array}{l}\text { Scenario Planning for Urban Planners: Toward } \\
\text { a Practitioner's Guide }\end{array}$ & USA & $\begin{array}{l}\text { (Chakraborty and McMillan } \\
\text { 2015a) [10] }\end{array}$ \\
\hline 34 & 2017 & $\begin{array}{l}\text { Developing a framework for collaborative } \\
\text { multi-agency scenario planning }\end{array}$ & Australia & $\begin{array}{l}\text { (C J Pettit, Hawken, and } \\
\text { Ticzon 2017) [70] }\end{array}$ \\
\hline 35 & 2019 & Scenario Planning Knowledge Base & USA & $\begin{array}{c}\text { American Planning } \\
\text { Association (APA 2019) [71] }\end{array}$ \\
\hline 36 & 2020 & $\begin{array}{l}\text { Scenario Planning for Cities and Regions } \\
\text { Managing and Envisioning Uncertain Futures }\end{array}$ & USA & (Goodspeed 2020) [72] \\
\hline
\end{tabular}

In the discussion of scenario planning for urban and regional planners, the prominent work is being done by the Lincoln Institute of Land Policy, which has been taking steps to document guidelines for the adoption of scenarios in urban studies $[8,9,72,73]$.

Parallel to the evolution of scenarios, there has been extensive progress on the design and adaptation of digital planning tools [51,74-78]. By digital planning tools, we refer to all kinds of ICT and GIS based decision support systems and planning support systems (PSS), which have been developed to aid urban planners in planning tasks. There is a wider acceptance and belief that the field of digital planning tools, especially PSS, has evolved as an effective contributor to support the planning process, and it greatly enhances the quality of planning outputs [75,79-87].

\subsection{A Review of Spatial Planning Practices in Pakistan}

As described in the previous section, academia and professional planners in USA, Australia and Europe are emphasizing and adopting the scenario planning approach either as a mainstream planning process, or as a sub-component of the larger urban planning process. However, the urban planners in Pakistan are still struggling with approaches that are almost outdated in their countries of origins.

In the last seventy years, many spatial planning solutions and plan types have been adopted in various cities. Qadeer believed that spatial plan making initially started as an effort to beautify the city, which then advanced to a process of development management [88]. Anjum has distributed the history of spatial planning in Pakistan in four eras. Stage 1: 1947-1960 when the focus was more on functional efficiency and public health, the segregation of land uses and the provision of infrastructure. Stage 2: 1960-1980 when the focus was on long-ranged, detailed land use plans, developed after extensive field surveys. This era was strongly influenced by the British 1947 Act, 
which resulted in the use of Master Plans, Landuse Plans and Zoning Plans. Stage 3: 1980-2000 focused upon long-ranged development plans prepared under national and regional policies, and the regulation of private sector land development. This was influenced by the British development plan system of the 1970s. Resultantly, we could see the Structure Plans and Local Plans being developed for many cities in Pakistan, along with the continued development of master plans and Outline Development Plans. Finally, stage 4: 2001-2008, which reflects urban planning after the Devolution Plan of 2001. This era focused on new century agendas and focused on private sector development, community involvement, environmental sustainability and demonstrative projects. However, in terms of plan shape, this era could not establish a definite answer to apply these concepts [15]. In 2009, Landuse Rules 2009 was introduced, resulting in the preparation of Peri-urban plans and Landuse Classification/Reclassification plans. This reflected a shift of focus from already developed built-up area to peri-urban areas, which were urbanizing at an alarming rate, resulting in major land use shifts. Voices were raised to limit urban boundaries and use geospatial technologies in the plan making process $[16,89]$. Consultants led planning remained dominating in the past decade. However, spatial planning could not become a top priority of the government; resultantly, the majority of the plans prepared after 2009 could never get approval. In 2019, the change of political government in Pakistan brought spatial planning to the limelight again. The government has initiated an ambitious 'Nya (new) Pakistan Housing Programme', which targets to deliver five million houses to public. Furthermore, they have emphasized the preparation of 'master plans' for all major urban centers.

So far, a few researchers in Pakistan have commented on the quality and efficacy of various spatial plans. Anjum, Ahmad and Hussnain have reviewed the spatial planning approaches and their products. Anjum and others have documented the stages in plan preparation process and have listed the major reasons behind the failure of plans in Pakistan $[15,20,21,90,91]$. Hameed et al. have commented on the master planning approach, and the challenges of implementing urban master plans [17]. Aziz et al. have focused on the implementation aspects of the master plan, and their discussion explains the institutional dynamics and legislative loopholes [92]. Adeel has assessed the challenges in the implementation of Rawalpindi Guided Development Plan, using remote sensing and GIS [93]. Hameed et al. have commented on the master plan for greater Lahore 1966, Lahore Urban Development and Traffic Study 1980 and Integrated Master Plan for Lahore 2021. They have observed and summed up the major deficiencies which led to the plans' failure. While documenting the reasons behind the failure of master plans, they raised questions about the nature and style of the development plan, which could respond to the cultural and institutional context and socio-economic and political realities of the country $[17,89]$. Khurshid has been advocating to think beyond conventional styled master plans $[94,95]$.

\section{Materials and Methods}

This research is exploratory in nature, which is geographically focused on Pakistan in terms of problem exploration, but looks at the global literature and international best practices for seeking solution. It uses mixed methods approach to achieve its objectives. To ascertain the urban spatial plans availability gap, it starts with the development of digital inventories (declared urban areas vs areas having spatial plans). After that, it uses the literature review to enlist factors that have contributed to the failure of various urban spatial plans in Pakistan. A two phased expert opinion survey from professional planners $(n=55)$ has been conducted to validate those factors and document the factor weights. A semi-systematic literature review has been conducted for scenario planning and its application in urban planning. Based on the web search, a list of urban planning projects has been compiled where scenario planning process has been used. The lessons from the scenario planning projects have been fused to the existing spatial planning process of Pakistan and a new step by step guide has been proposed to make future spatial plans in Pakistan.

1. Extraction of declared urban areas from the census data Every national census (1951, 1961, 1972, 1981, 1998 and 2017) has declared a set of settlements as 'urban', based on varied definitions. 
The census data has been published by Pakistan Bureau of Statistics in the form of PDF documents without digitally sortable tables. PDF to MS Excel conversion with optical character recognition (OCR) techniques, along with a Python based rows sorting mechanism, have been applied to extract data, which was then manually sorted to pick urban settlements. Finally, a matrix has been generated to document the increase in the number of declared urban settlements over the census periods among various provinces. The urban settlements have been mapped using the geocoding process to visualize the temporal increase in urban areas. To geocode the place names, a combination of Google Fusion Tables and place names from Open Street Maps (www.openstreetmap.org) and City Population (http://citypopulation.de/) have been used (See Figure 1).

2. Prepare an inventory of all spatial plans in Pakistan From the review of online resources and departmental libraries, a list of spatial plans has been developed, along with key meta data attributes, including spatial plan type, preparing agency, year of preparation, plan duration, approval status and status of plan validity. It is important to highlight that most of the previous plans have been collected in a printed or scanned format, which are not computer text readable. Hence, we have done a manual meta data listing for the preparation of an inventory, instead of a content based lexical analysis. Entries for the inventory have been searched and populated from multiple sources, listed in Table 2. An effort has been made to collect the means of verifications for each entry in terms of the plan document and/or plan map.

3. Literature Review: The literature review has been conducted for two key purposes. First, to understand what has been documented about the causes behind the failure of various urban spatial plans. This review is geographically focused on Pakistan. Second, a semi-systematic review of the published literature has been conducted on a global scale, using EBSCO, Google Scholar, Web of Science and Scopus, to explore the application of scenarios in urban planning. Key terms used for searching include "scenario planning", "scenario and urban planning", "scenario planning applications", "scenario method in land use planning", "scenario in urban planning projects". A lot has been written on the scenario method in general, so attention was paid to exploring the application side in the urban planning domain. Furthermore, an effort was made to enlist urban planning projects where scenario planning has been adopted as a process. Lessons from the projects have been used to improvise the spatial plan-making process for Pakistan.

4. Experts opinion survey: A two-phased survey of urban planning experts have been conducted in 2019, to record their opinion about the factors behind the failure of urban spatial plans and experts' aspiration for a futuristic plan-making process. A total of 55 urban and regional planners were contacted, out of which 46 responded. The survey recruitment criteria included "qualified urban and regional planners", "more than 10 years of experience" and "involvement in a previous urban spatial plan-making process". An effort was made to get respondents from academia, government, industry and non-government sectors, along with representation from all provinces. In the first phase, experts were asked to share their opinion about "how well the spatial plans were able to achieve their objectives in Pakistan?" on a Likert scale of 1 to 10, where 1 equates not at all, complete failure; $5=$ neutral and $10=$ to a great extent. They were asked to qualitatively describe the causes behind the failure of spatial plans in narrative form. The qualitative data, so collected, were analyzed using the Selective Lexicon Approach-Level-3 [96]. Resultantly, the key words were generated, and a list of 26 factor statements were developed against seven major stages of traditional plan making process. The seven stages were also derived from the literature review, and the first round of experts' opinion. In the second phase, the list of twenty-six factor-statements was presented to the experts, to express their opinion about the contribution of each factor towards the failure of urban spatial plans on a 5-point Likert scale. Furthermore, experts were asked to select which type of urban spatial plans (master plan, outline development plan, peri-urban structure plan, regional plans, structure plan) have performed better in the context of Pakistan and why. In addition, experts were asked to respond some open-ended questions, to document 
their suggestions on potential improvements in the spatial plan-making process, the viability of data-driven planning and readiness for adopting future-oriented planning approaches.

5. Finally, the research synthesizes the lessons and findings of all the above-mentioned processes, and concludes by offering a way forward.

Table 2. Sources of spatial plan documents in Pakistan.

\begin{tabular}{cccc}
\hline Sr. No & Source & Website & Coverage \\
\hline 1 & The Urban Unit, Lahore & http://www.urbanunit.gov.pk/ & Punjab Province \\
\hline 2 & $\begin{array}{c}\text { Punjab Housing and Town Planning } \\
\text { Agency }\end{array}$ & $\begin{array}{c}\text { https: } \\
\text { /hudphed.punjab.gov.pk/phata1 }\end{array}$ & Punjab Province \\
\hline 3 & Urban Policy Unit, Peshawar & http://urbanpolicyunit.gkp.pk/ & $\begin{array}{c}\text { Khyber Pakhtunkhwa } \\
\text { Province }\end{array}$ \\
\hline 4 & Directorate of Urban Policy and & http: & Sindh Province \\
\hline 5 & Sindh Cities Improvement Program & //www.urbandirectorate.gos.pk/ & Sindh Province \\
\hline 6 & North Sindh Urban Services & - & Sindh Province \\
\hline 7 & Corporation Limited (NSUSC) & http://www.nsusc.org.pk/ & Across Pakistan \\
\hline
\end{tabular}

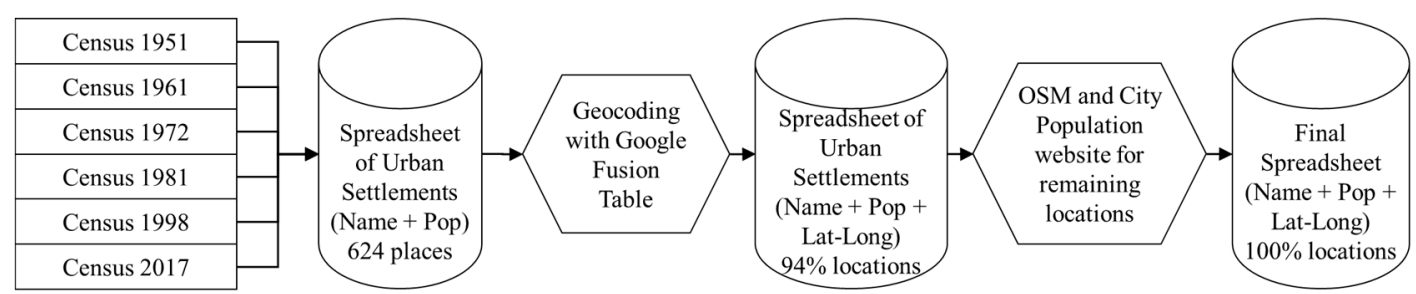

Figure 1. Data preparation process for listing of declared urban areas.

\section{Discussion and Results}

\subsection{Documentation of Declared Urban Areas vs. Spatial Plans' Availability}

The compilation of the urban areas and its spatial mapping reveals Punjab to be the densest province, containing 257 declared urban areas, as per the census of 2017, followed by Sindh, which has 197 urban areas. The third place is attained by Khyber Pukhtunkhwa (KPK) province, which has 62 urban areas. Baluchistan, the largest province in terms of the area, is fifth place, with 61 urban centers. After that, Azad Jammu \& Keshmir (AJK) has 25, Federally Administered Tribal Area (FATA) has 16, while Gilgit Baltistan has five declared urban areas (See Table 3).

Table 3. Inter censual provincial distribution of declared urban areas.

\begin{tabular}{ccccccc}
\hline Province & $\mathbf{1 9 5 1}$ & $\mathbf{1 9 6 1}$ & $\mathbf{1 9 7 2}$ & $\mathbf{1 9 8 1}$ & $\mathbf{1 9 9 8}$ & $\mathbf{2 0 1 7}$ \\
\hline AJK & & 1 & 1 & 1 & 7 & 26 \\
Balochistan & 17 & 30 & 34 & 31 & 46 & 61 \\
FATA & & 2 & 2 & & 5 & 16 \\
GB & & & & & 5 & 5 \\
ICT & & & 1 & 1 & 1 & 1 \\
KPK & 28 & 39 & 42 & 42 & 54 & 62 \\
Punjab & 145 & 164 & 193 & 208 & 242 & 257 \\
Sindh & 31 & 66 & 103 & 127 & 159 & 196 \\
Grand Total & 221 & 302 & 376 & 410 & 519 & 624 \\
\hline
\end{tabular}

As compared to the previous census of 1998, the highest increase in the number of declared urban areas appear in Sindh province, which has 37 new urban places, followed by AJK, having 19 new 
places, Baluchistan and Punjab both have 15 new localities, FATA has 11, while KPK has eight new settlements declared as urban.

To have a deeper look at the phenomena, the urban settlements have been mapped down based on their geographic coordinates (see Figure 2, where one dot represents one urban settlement). It is clear that the increase in number and size of cities in Punjab and Sindh provinces is along the water bodies and agriculturally rich areas, which are considered the food basket for Pakistan.

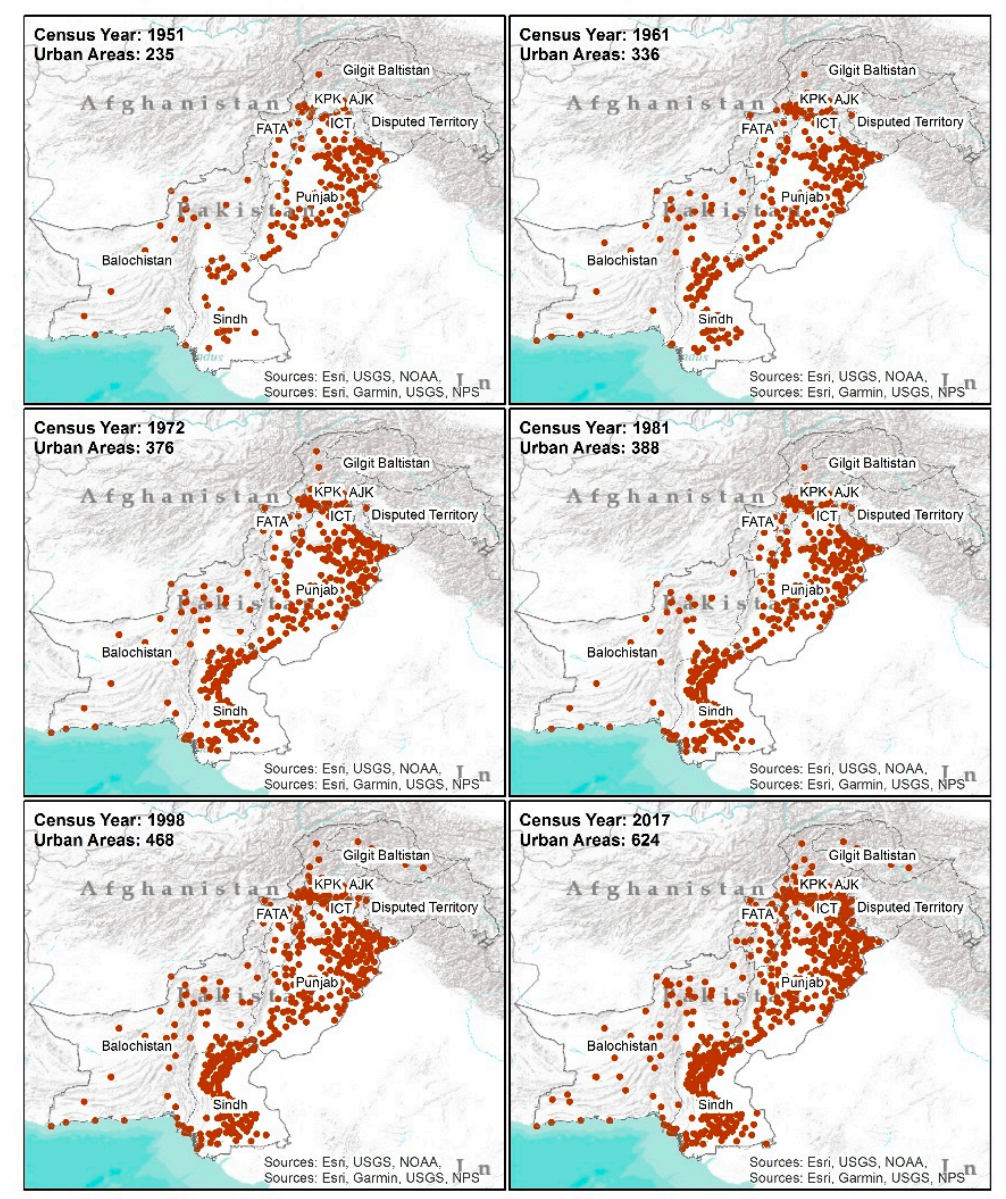

Figure 2. Increase in the number of declared urban areas over the census (authors' own construct, based on the census data. Municipal Committee areas and Cantonments for same settlement are marked as one point).

In summary, there has been a substantial increase in the declared urban areas and their sizes. As per the latest census, urban planners and city managers have to focus on 624 urban settlements to prepare their spatial plans, out of which, a significant proportion (36\%) are inhabited by more than 50,000 people.

After the quantification of urban settlements at the national level, this research has enlisted and mapped the availability of spatial plans. The analysis reveals that out of 624 declared urban areas, only 179 could ever had a spatial plan, leaving more than $70 \%$ of the cities to grow without a spatial plan (see Figure 4). Table 4 presents the detailed statistics on the availability of spatial plans, their validity and approval status. If we consider all the plans which have been made for urban areas (duplication considered), it can be noted that 229 spatial plans of various forms have been prepared in different periods, out of which only 162 could get formal approvals. Considering the plan periods, only 102 plans (both approved and unapproved) were still valid in 2019, while 111 expired. 
Table 4. Urban spatial plans availability gap by province.

\begin{tabular}{|c|c|c|c|c|c|c|c|c|c|}
\hline \multirow{2}{*}{ Provinces } & \multirow{2}{*}{$\begin{array}{l}\text { Declared } \\
\text { Urban } \\
\text { Areas }\end{array}$} & \multirow{2}{*}{$\begin{array}{l}\text { Cities That } \\
\text { Ever Had a } \\
\text { Spatial Plan } \\
\text { (Unique) }\end{array}$} & \multirow{2}{*}{$\begin{array}{c}\text { Total Plans } \\
\text { Prepared (Including } \\
\text { Cities with } 2 \text { or } \\
\text { More Plans) }\end{array}$} & \multicolumn{3}{|c|}{ Approval Status } & \multicolumn{3}{|c|}{$\begin{array}{c}\text { Validity Based on Plan } \\
\text { Period }\end{array}$} \\
\hline & & & & Approved & $\begin{array}{c}\text { Not } \\
\text { Approved }\end{array}$ & $\begin{array}{c}\text { Not } \\
\text { Known }\end{array}$ & $\begin{array}{l}\text { Valid } \\
\text { in } 2019\end{array}$ & Expired & $\begin{array}{c}\text { Not } \\
\text { Known }\end{array}$ \\
\hline AJK & 26 & 9 & 9 & 9 & & & 9 & & \\
\hline Balochistan & 61 & 2 & 2 & 2 & & & 2 & & \\
\hline FATA & 16 & 0 & 0 & & & & & & \\
\hline KPK & 62 & 2 & 5 & 3 & 2 & & 2 & 3 & \\
\hline Punjab & 257 & 140 & 171 & 145 & 25 & 1 & 70 & 101 & \\
\hline Sindh & 196 & 23 & 36 & 1 & & 35 & 17 & 3 & 16 \\
\hline Total & 624 & 179 & 229 & 162 & 31 & 36 & 102 & 111 & 16 \\
\hline
\end{tabular}

Spatial mapping of the urban areas that do or do not have an urban plan reflects interesting patterns. Keeping the validity aside, in Punjab, 54\% $(n=140)$ of urban areas have some form of spatial plan, 35\% $(n=9)$ in AJK, 12\% $(n=23)$ in Sindh, 3\% $(n=2)$ in KPK and in Baluchistan. Furthermore, plotting the spatial plans by type also yields interesting patterns (see Figure 3). The practice of preparing outline development plans and peri-urban structure plans has been more influential in Punjab, while Sindh has mostly adopted the master plans. Furthermore, the master plans have been prepared for the large cities, as compared to the smaller towns.

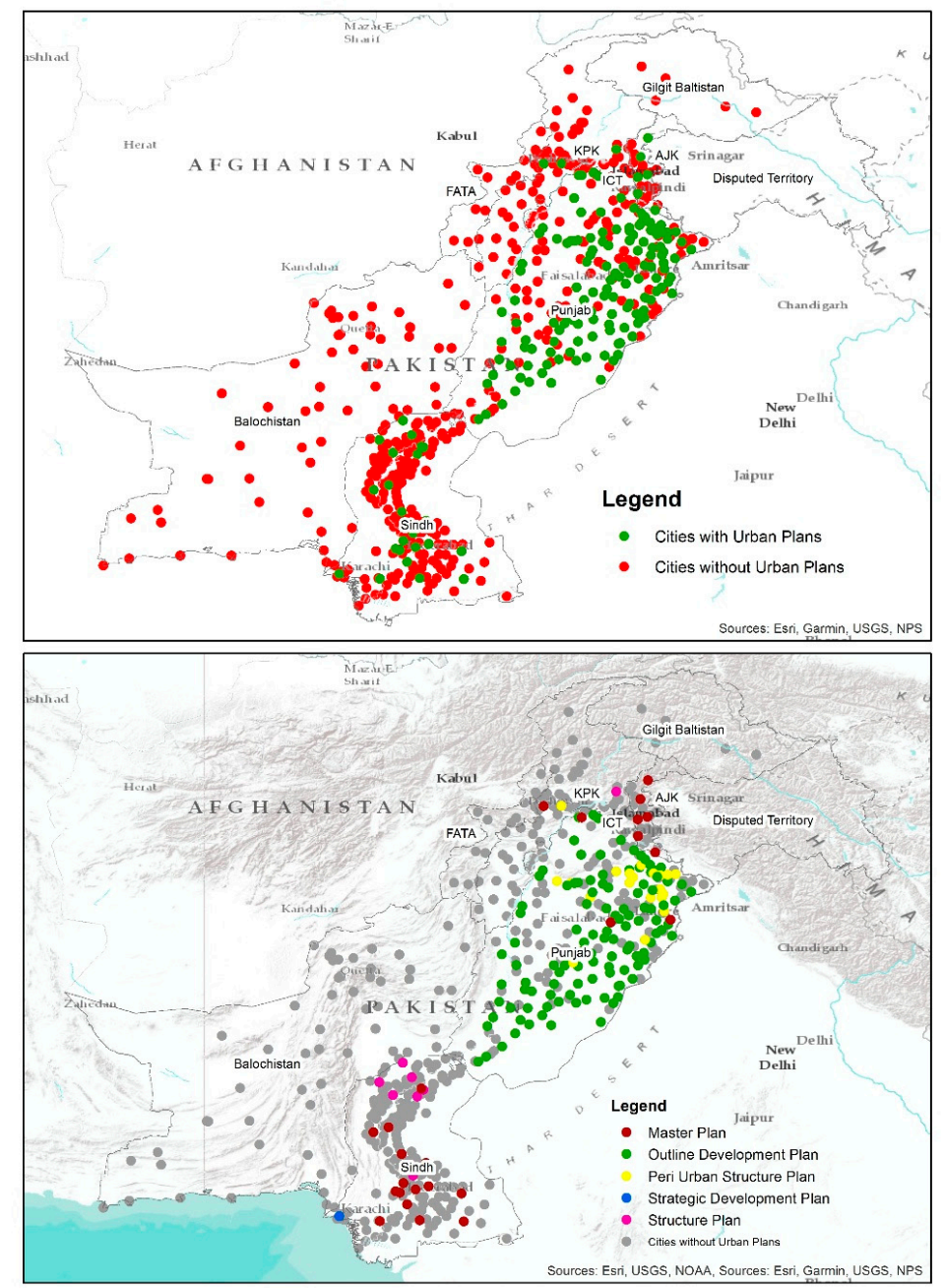

Figure 3. Cities with or without an urban spatial plan (top), spatial distribution of various types of urban plans (bottom). 
This analysis reveals that majority of the urban settlements (83\%) in Pakistan are growing without a valid plan, and there is a dire need to focus on the preparation of spatial plans to control the harmful aspects of urbanization. There are a wide variety of spatial plans which have been tested by the development authorities, offering a broader spectrum to evaluate and learn from previous practices.

\subsection{Factors Contributing to the Failure of Spatial Plans}

To examine the factors contributing to the failure of spatial plan, a two phased expert opinion survey has been conducted. The frequency distributions of valid responses $(n=46)$ reveals that $24 \%$ of the experts belong to academia, 38\% form government, $31 \%$ from industry and $7 \%$ belonged to non-government organizations. In terms of provincial distribution of responses, $64 \%$ experts have been from Punjab, 9\% from Khyber Pakhtunkhwa and Islamabad Capital Territory each, $7 \%$ from overseas Pakistani planners and 2\% from Baluchistan and Gilgit Baltistan each.

In line with the findings of the literature, the majority of the urban planners $(62 \%)$ believed that urban spatial plans have not been able to achieve their objectives in Pakistan. A total of $13 \%$ gave a neutral response, while $24 \%$ responded on the positive side of the Likert scale, reflecting their opinion that plans have been able to achieve their objective to some extent.

When it comes to the identification of factors which have contributed to the failure of spatial plans and their average factorial ranking, factors related to the 'collaborated action' have been ranked as the most significant contributors, with an average score of 9.21, followed by factors linked to the stage of the 'implementation framework', having an average score of 8.92. Furthermore, the factors related to the 'goal formulation' has been scored at 7.6, followed by factors under 'stakeholder \& community participation' with 7.18, and 'planning proposals formulation' with 6.75, 'detailed planning' with 6.56 and 'baseline studies' related factors with a 6.34 average score (see Figure 4a)

a) Factorial contribution of plan making stages in the failure of spatial plans

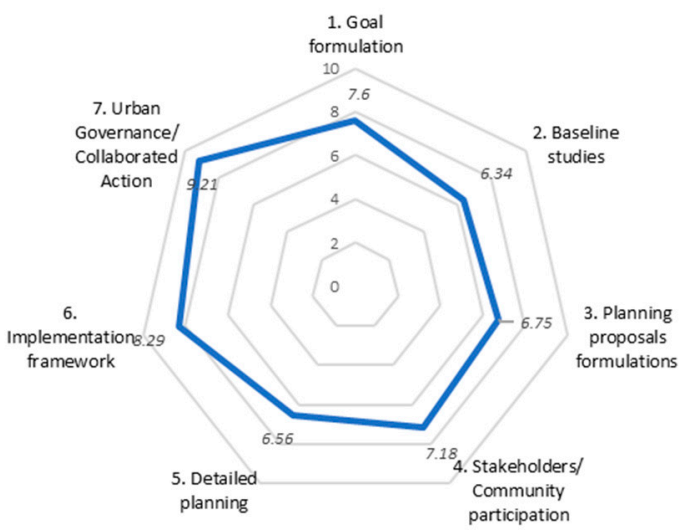

b) Stage wise strength of current spatial planning practice

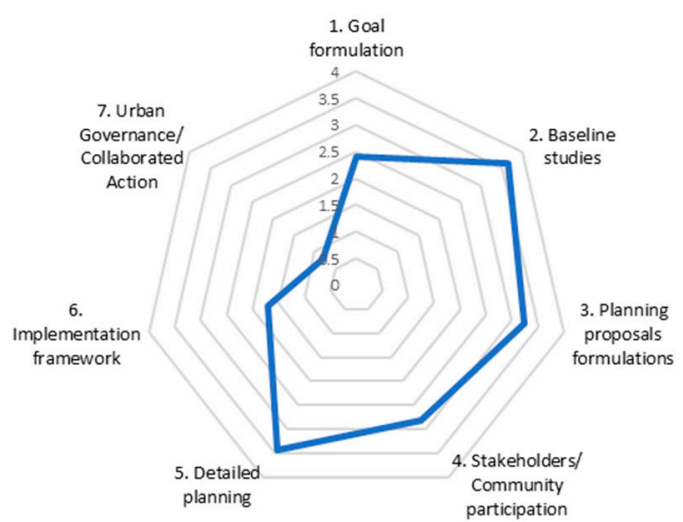

Figure 4. (a) Factorial contribution of plan making stages in the failure of spatial plans, (b) stage wise strength of current spatial planning practice.

On the one hand, when we explore the strengths of the stages, the analysis reveals that the stage-7 'urban governance/collaborated action' is at the weakest position, with a score of 0.79 , followed by the stage- 6 'implementation framework', with a score of 1.71 and stage-1 'goal formulation', having a score of 2.4. These stages require corrective intervention in terms of theoretical input and execution tools. On the other hand, the strongest position has been attached by the stage-2 'baseline studies', with a score of 3.66, followed by the stage-5 'detailed planning', which has attained 3.44. Similarly, stage-3 'planning proposals formulations' and stage-4 'stakeholders/community participation' have scores of 3.25 and 2.82 respectively (See Table 5 and Figure $4 b$ ). 
Table 5. Plan making stages as a 'contributor to failure' vs. strengths of traditional plan making process in each stage.

\begin{tabular}{cccc}
\hline Urban Plan Making Stage & $\begin{array}{c}\text { No. of } \\
\text { Factors }\end{array}$ & $\begin{array}{c}\text { Score Representing Stage's Role } \\
\text { as ‘Contributor to Failure' }\end{array}$ & $\begin{array}{c}\text { Strength of Traditional } \\
\text { Plan Making Process }\end{array}$ \\
\hline 1. Goal formulation & 2 & 7.6 & 2.4 \\
2. Baseline studies & 3 & 6.34 & 3.66 \\
3. Planning proposals formulations & 9 & 6.75 & 3.25 \\
4. Stakeholders/Community participation & 4 & 7.18 & 2.82 \\
5. Detailed planning & 3 & 6.56 & 3.44 \\
6. Implementation framework & 4 & 8.29 & 1.71 \\
7. Urban governance & 2 & 9.21 & 0.79 \\
\hline
\end{tabular}

After a deeper dive within the stages, Table 6 presents the stage wise listing and ranking of 27 factors contributing to the failure of urban spatial plans. At the stage of goal formulation, this included the 'clarity of the implementation agency about the plan type and contents', with an importance score of 7.35 and 'inability of the agency in prioritizing relevant important themes and ensuring mechanism to assign due priority to the selected themes', with a score of 7.85. At the stage of baseline studies, three factors have been identified, which include 'absence/wrong collection of relevant data' (6.58), 'insufficient data collection' (6.22) and 'inadequate usage of digital planning tools (IT, GIS, PSS and RS)' (6.22). At the stage of planning proposals formulation, nine of the identified factors included 'inability of plan proposals to match with future vision and the absence of mechanism to establish link of proposal with future vision' (7.45), 'absence or inadequacy of alternate proposals' (7.35), 'inability of plan making process to consider all relevant planning variables' (7.04), 'inaccuracy of future estimates and projections' (6.89), 'insufficient data analysis' (6.68), 'insufficient alternate proposals' (6.58), 'high time investment on data collection as compared to synthesize in proposal making' (6.43), 'unexpected changes in the real world' (6.22) and 'weak contents and lack of comprehensiveness (thematic \& geographic coverage)' (6.07). Similarly, under the stage of stakeholders/community participation, four factors have been listed, which include 'lack of community participation' (7.76), 'lack of stakeholders' engagement' (7.70), 'inability to effectively ensure incorporation of stakeholders' opinions'(7.50) and 'more focused on donor driven agenda rather than local agency's needs' (5.77).

Table 6. Stage wise listing and ranking of factors contributing to the failure of urban spatial plans.

\begin{tabular}{|c|c|c|c|}
\hline Urban Plan Making Stages & $\begin{array}{l}\text { Factor } \\
\text { Label }\end{array}$ & Factors Contributing to the Failure of Plans & $\begin{array}{l}\text { Importance } \\
\text { (Scale 1-10) }\end{array}$ \\
\hline \multirow{2}{*}{ 1. Goal formulation } & 1.1 & $\begin{array}{l}\text { Clarity of the implementation agency about the } \\
\text { plan type, contents and scale }\end{array}$ & 7.35 \\
\hline & 1.2 & $\begin{array}{l}\text { Inability of the agency in prioritizing relevant } \\
\text { important themes and ensuring mechanism to } \\
\text { assign due priority to the selected themes }\end{array}$ & 7.85 \\
\hline \multirow{3}{*}{ 2. Baseline studies } & 2.1 & Absence/wrong collection of relevant data & 6.58 \\
\hline & 2.2 & Insufficient data collection & 6.22 \\
\hline & 2.3 & $\begin{array}{l}\text { Inadequate usage of digital planning tools (IT, } \\
\text { GIS, PSS and RS) }\end{array}$ & 6.22 \\
\hline \multirow{4}{*}{$\begin{array}{l}\text { 3. Planning proposals } \\
\text { formulations }\end{array}$} & 3.1 & $\begin{array}{l}\text { Inability of plan proposals to match with future } \\
\text { vision and the absence of mechanism to } \\
\text { establish link of proposal with future vision }\end{array}$ & 7.45 \\
\hline & 3.2 & Absence or Inadequacy of alternate proposals & 7.35 \\
\hline & 3.3 & $\begin{array}{l}\text { Inability of plan making process to consider all } \\
\text { relevant planning variables }\end{array}$ & 7.04 \\
\hline & 3.4 & Inaccuracy of future estimates and projections & 6.89 \\
\hline
\end{tabular}


Table 6. Cont.

\begin{tabular}{|c|c|c|c|}
\hline Urban Plan Making Stages & $\begin{array}{l}\text { Factor } \\
\text { Label }\end{array}$ & Factors Contributing to the Failure of Plans & $\begin{array}{l}\text { Importance } \\
\text { (Scale 1-10) }\end{array}$ \\
\hline & 3.5 & Insufficient data analysis & 6.68 \\
\hline & 3.6 & Insufficient alternate proposals & 6.58 \\
\hline & 3.7 & $\begin{array}{l}\text { High time investment on data collection as } \\
\text { compared to synthesize in proposal making }\end{array}$ & 6.43 \\
\hline & 3.8 & Unexpected changes in the real world & 6.22 \\
\hline & 3.9 & $\begin{array}{l}\text { Weak contents and lack of comprehensiveness } \\
\text { (thematic \& geographic coverage) }\end{array}$ & 6.07 \\
\hline \multirow{4}{*}{$\begin{array}{l}\text { 4. Stakeholders/Community } \\
\text { participation }\end{array}$} & 4.1 & Lack of community participation & 7.76 \\
\hline & 4.2 & Lack of stakeholders' engagement & 7.70 \\
\hline & 4.3 & $\begin{array}{l}\text { Inability to effectively ensure incorporation of } \\
\text { stakeholders' opinions }\end{array}$ & 7.50 \\
\hline & 4.4 & $\begin{array}{l}\text { More focused on donor driven agenda rather } \\
\text { than local agency's needs }\end{array}$ & 5.77 \\
\hline \multirow{3}{*}{ 5. Detailed planning } & 5.1 & Insufficient skills of the plan making teams & 6.73 \\
\hline & 5.2 & Faulty plan making approach & 6.58 \\
\hline & 5.3 & Faulty plan preparation process & 6.38 \\
\hline \multirow{4}{*}{$\begin{array}{l}\text { 6. Implementation } \\
\text { framework }\end{array}$} & 6.1 & $\begin{array}{l}\text { Insufficient capacity of plan implementation } \\
\text { agency }\end{array}$ & 8.78 \\
\hline & 6.2 & $\begin{array}{l}\text { Absence of legal backing for plan } \\
\text { implementation }\end{array}$ & 8.32 \\
\hline & 6.3 & Delayed plan approval & 8.16 \\
\hline & 6.4 & $\begin{array}{l}\text { Absence of financial model to execute planning } \\
\text { proposals }\end{array}$ & 7.91 \\
\hline \multirow{2}{*}{ 7. Urban Governance } & 7.1 & Weak enforcement mechanism & 9.29 \\
\hline & 7.2 & Lack of ownership by implementing agency & 9.13 \\
\hline
\end{tabular}

Furthermore, at the stage of detailed planning, three factors have been identified, including 'insufficient skills of the plan making teams or absence of town planning professionals in the team' (6.73), 'faulty plan making approach' (6.58) and 'faulty plan preparation process' (6.38). At the stage of the implementation framework, four listed factors include: 'insufficient capacity of plan implementation agency' (8.78), 'absence of legal backing for plan implementation' (8.32), 'delayed plan approval' (8.16) and 'absence of financial model to execute planning proposals' (7.91). Last but not least, the stage of urban governance/collaborated action contains two factors, including 'weak enforcement mechanism' (9.29) and 'lack of ownership by implementing agency' (9.13) (see Figure 5). 
Factors contributing to the failure of Spatial Plans

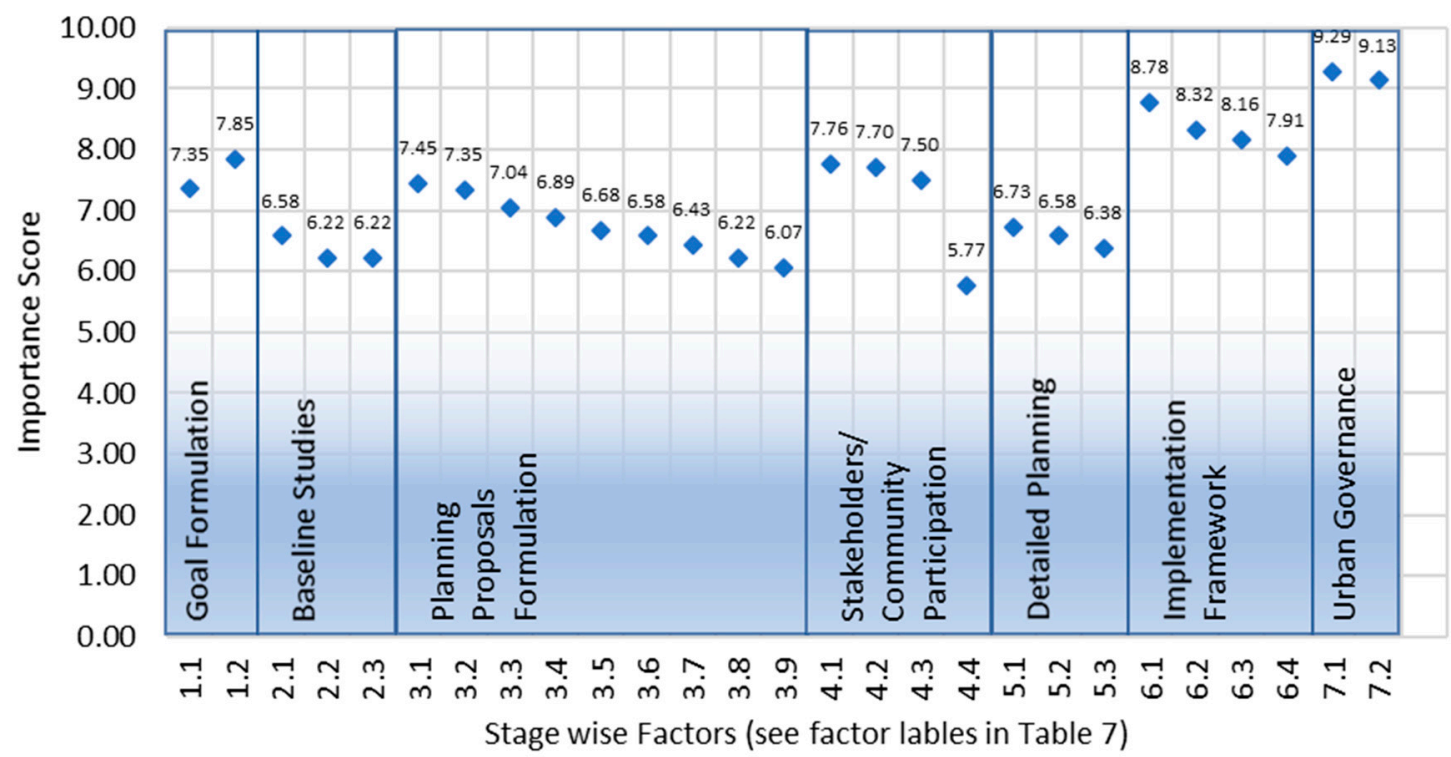

Figure 5. Factors contributing to the failure of spatial plans.

\subsection{Scenario Planning; a Promising Solution to Uncertainty and Complexity}

From the review of the literature on the applications of the 'scenario' method in urban planning, it is clear that scenario planning is particularly useful for decision making in the face of an uncertain future. Since it is not a separate planning process, it should be better used to build flexibility in the existing planning process.

Based on the real-life applications, scholars have extensively documented the benefits of scenario planning in generating dialogue among the stakeholders, unfolding conflicting agendas and helping the urban planning players understand the impacts of stakeholders' actions on other linked cycles. The scenario method is particularly useful in: (a) setting goals and imagining future preferred shape of the urban area, (b) the development of alternate proposals, (c) the meaningful engagement of stakeholders, (d) chalking out the implementation of frameworks and (e) identifying workable means for collaborative action.

\section{Future Shape of the Spatial Plans}

In the previous section, Figure $5 \mathrm{~b}$ has indicated the areas which should be addressed to improve the situation. Considering the successful application of 'scenarios' and 'digital planning tools, especially planning support systems' in the spatial plan making process, we recommend that the lessons of these two knowledge streams must be incorporated in the traditional planning process of Pakistan to improve the process.

Since the factors behind spatial plans' failure have been organized against plan making stages, let us examine how the proposed approach and tools can fix and improve each stage. Figure 6 gives a graphical illustration of the type of intervention required at every plan making stage.

At the stage of goal formulation, scenario planning can greatly help stakeholders in clarifying stakeholders' vision. It allows all the stakeholders to focus on what is important for an urban area and how they want to grow to reach that goal [9].

During baseline studies, scenario based digital planning tools can help focusing on the collection of relevant data [51]. Adopting ICT based solutions and digital planning tools can ensure the sufficiency and efficacy of data. Furthermore, the use of digital planning tools (RS/GIS/PSS) can ensure time and cost efficiency [21,91,97]. 


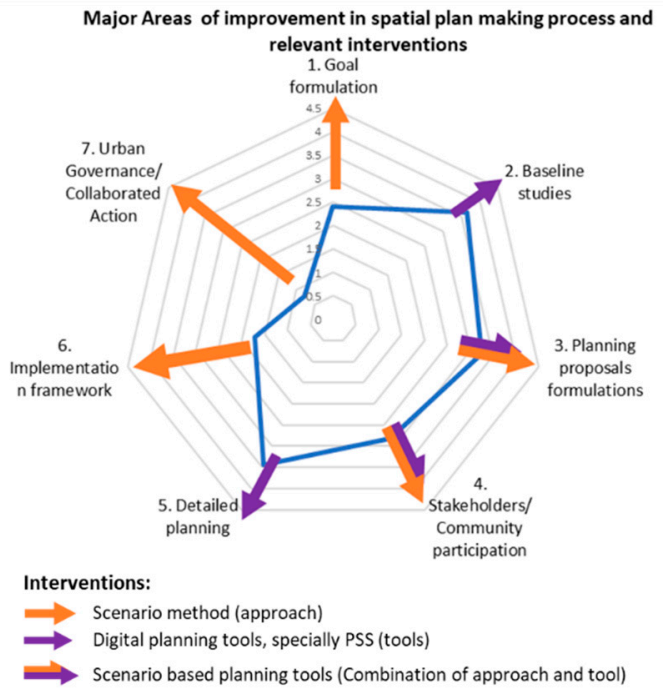

Figure 6. Major areas of improvement in spatial plan making process and relevant interventions.

At the stage of planning proposals formulation, scenario method can help clarify the 'actors' and their potential roles in the shaping the future of cities. As an approach, building scenarios helps stakeholders to ensure that all relevant planning variables are being duly considered in the proposal formulation. The alternate scenarios help in formulating and assessing the proposals and their potential impacts. The traditional planning process lack the means to ascertain the future result of choices that can be easily handled by scenario planning. Scenario planning gives confidence to planners and decision makers that the logical input-out chain is well established, and that the chosen option will or will not lead to the desired goals. Furthermore, the use of scenario planning tools can ensure that future estimations are reasonably accurate and are in line with the ground realities. Planning support system allow the stakeholders to try out various scenario combinations and see the changes in real time [98].

A prominent benefit of adopting scenario planning and planning support systems is their ability to engage community and stakeholders in the planning process. Scenarios unfold hidden agendas and make the process transparent. They let community and stakeholders think outside the box and come up with innovative solutions to the problem at hand. Similarly, the ability to demonstrate the resulted changes on screens and dashboards make PSS extremely powerful in creating communal engagements, and ignite thinking process in focus groups.

In traditional planning, planning proposals are prepared in isolation, and the integrated impact of various proposals is hard to ascertain. Digital planning tools use a full spectrum approach, where it is not possible to hide any assumptions. They require planners to work out proposal in a detailed level. For instance, Envision Tomorrow PSS require plan makers to specify land uses for every parcel of the land and specify variables for each land use to generate an overall picture of the city. Similarly, Online WhatIf? PSS require the suitability factors to be very specific and comprehensive in order to generate future development scenarios. Resultantly, plan making teams work in a systematic and detailed manner, rather than overly simplifying the proposals.

\section{Conclusions and Future Work}

The continued pressure of urbanization has resulted in a rapid increase of declared urban areas in Pakistan from 468 to 624 from 1998 to 2017, respectively. In addition to the definitional issues within census report, these urban areas were not previously mapped to ascertain their geographical spread. Based on the synthesis of hard copy census reports from 1951 to 2017, this research produces a unique dataset that is purely focused on urban areas. Issues related to naming conventions have been resolved; resultantly, it is possible to track changes in an urban area from 1951 to 2017. After linking 
the geographic coordinates to each declared settlement, it offers the very first geospatial dataset on declared urban centers in Pakistan. To create a wider impact, the dataset has been shared in open domain through PakistanGIS (www.PaksitanGIS.org; a Pakistan based forum to share open sourced geospatial datasets). Furthermore, based on the data of this research an online portal (accessible at www.PakistanUrbanPortal.org) has been established, which offers free access to the data and documentation on urban areas in Pakistan. Opening access to the data inventories presented in this research will resolve a key research barrier in the country, and can be used further to develop urban dashboards and visual platforms to support greater transparency and participation in the planning process, as discussed by Lock [99].

On the response side of rapid urbanization, development control agencies in Pakistan have been slow in preparing spatial plans, and a wide variety of spatial plan types have been prepared and executed. This research creates a national level digital inventory of spatial plans, which have been prepared across Pakistan. Comparing this inventory with the declared urban areas list has given us the spatial plans' availability gap. Results have been mapped as point data across Pakistan to see the spatial pattern across provinces. The widest gap exists in the Baluchistan and KP provinces, where only $3 \%$ of the urban areas have got their plans. In Sindh, $88 \%$ of the urban areas do not have a plan, in AJK it is $65 \%$, while in Punjab, $46 \%$ of the urban areas do not have a future spatial plan. This presents an alarming picture for the development controlling agencies. However, the realization of these facts has been initiated. On many of the events organized on the World Town Planning Day (WTPD) 2019, planning professionals have raised a voice to declare an 'urban planning emergency' in the country, where all the left out urban areas should be prioritized for a future growth spatial plan.

Since there is an uprising of interest in the formulation of master plans for all cities in Pakistan, this research examines the factors behind the failure of past plans. A survey of 55 professional planners, engaged in past spatial plan making projects has been conducted to enlist and rank more than twenty-five factors contributing to the failure of plans on various stages of plan making. Ideas have been collected about the solutions to improve the conditions that have been triangulated from the world best practices of spatial plan making.

The review of the literature and the synthesis of the applications of scenario method in urban planning projects across the advanced world reflects the fact that 'scenario planning' (as approach) and associated 'digital planning tools and planning support systems' (as tools) are leading and promising solutions, which can counter most of the failure causing factors.

This research presents how the integration of 'scenario planning' and 'digital planning tools' in the spatial plan-making process can offer a solution to the plan making challenges. Considering the ground realities of Pakistan, a new process of spatial plan-making has been proposed, which is the fusion of scenario planning and the traditional plan-making process, backed by digital planning tools. However, the execution of this approach will not be an easy task. The capacity of planners in adapting the scenario approach, as well as applying planning support systems, can be a major stumbling block. Like the initiatives in other countries, there is a need to incorporate scenario planning in the core curriculum of urban planning schools in Pakistan and other developing countries, and to educate urban planning professionals on the approach. This aligns with recommendations by Russo et al. [100] in studying the use of planning support systems in Italy, Switzerland and Australia. Further research is needed to outline detailed procedural steps for incorporating the scenario method in spatial planning process [101].

Author Contributions: M.Q.u.H., A.W., G.A.A.; methodology, M.Q.u.H., A.W., G.A.A., and C.J.P.; software, K.W. and M.Q.u.H.; validation, M.Q.u.H., K.W.; formal analysis, M.Q.u.H.; investigation, M.Q.u.H., A.W., E.H., M.A.N.; resources, M.Q.u.H., A.W.; data curation, M.Q.u.H.; writing-original draft preparation, M.Q.u.H., A.W., K.W.; writing-review and editing, A.W., C.J.P.; visualization, M.Q.u.H.; supervision, A.W., G.A.A., E.H., M.A.N.; project administration, M.Q.u.H. and A.W.; funding acquisition, M.Q.u.H., A.W. All authors have read and agreed to the published version of the manuscript.

Funding: This research received no external funding. 
Acknowledgments: We want to thank the anonymous reviewers whose comments and suggestions contributed a lot in the refinement of research methodology and write-up.

Conflicts of Interest: The authors declare no conflict of interest.

\section{References}

1. ABS. Australian Statistical Geography Standard (ASGS): Volume 4-Significant Urban Areas, Urban Centres and Localities. 2017. Available online: https://www.abs.gov.au/ausstats/abs@.nsf/Lookup/bySubject/1270.0. 55.004 \{\}July2016 \{\}MainFeatures \{\}DifferentDefinitionsofUrban \{\}6 (accessed on 10 April 2020).

2. Adeel, M. Assessing the Implementation of Rawalpindi's Guided Development Plan through GIS and Remote Sensing. 2010. Available online: http://geomultimedia.at/archive/CORP2010_201.pdf (accessed on 15 May 2020).

3. Afzal, M. Evaluation of Peri-Urban Structure Plan Practices in Punjab. Master's Thesis, University of Engineering and Technology, Lahore, Pakistan, 2016.

4. Ahmad, N. Development Plan Practices to Manage Spatial Growth in Major Cities of Pakistan a Case Study of Peshawar City; University of Engineering and Technology: Lahore, Pakistan, 2012. Available online: http://prr.hec.gov.pk/jspui/handle/123456789/2768 (accessed on 15 May 2020).

5. Ahmad, N.; Ghulam, A.A. Legal and Institutional Perplexities Hampering the Implementation of Urban Development Plans in Pakistan. Cities 2012, 29, 271-277. [CrossRef]

6. Ali, R. Underestimating Urbanization. Econ. Political Wkly. 2002, XXXVII, 44-45. Available online: https://mittalsouthasiainstitute.harvard.edu/wp-content/uploads/2013/10/1-Underestimatingurbanisation.pdf (accessed on 15 May 2020).

7. Arif, D. Estimating Urbanization. Urban Gazettee. 2013. Available online: https://mittalsouthasiainstitute. harvard.edu/wp-content/uploads/2013/10/Estimating-Urbanization.pdf (accessed on 15 May 2020).

8. Angel, S.; Sc, S. The Dynamics of Global Urban Expansion. Transp. Urban 2005. [CrossRef]

9. Anjum, G.A. Assessment of Urban Land Development and Management Practices in Five Cities of Punjab. Lahore. 2008. Available online: http://www.urbanunit.gov.pk/PublicationDocs/28.pdf (accessed on 19 March 2017).

10. APA. Scenario Planning Knowledge Base. 2019. Available online: https://www.planning.org/knowledgebase/ scenarioplanning/ (accessed on 15 May 2020).

11. Arif, G.M.; Sabiha, I.; Tauseef, A. The Process of Urbanisation in Pakistan, 1951-1998. Pak. Dev. Rev. 1998, 37, 507-522. Available online: http://www.jstor.org/stable/41261068 (accessed on 15 May 2020). [CrossRef]

12. Aziz, A.; Shakir, M.M.; Ijaz, A. Master Planning Under Legislative and Organizational Impediments (A Case Study of Lahore). Tech. J. Univ. Eng. Technol. (UET) Taxila Pak. 2014, 19. Available online: http://tj.uettaxila.edu. pk/older-issues/2014/No4/6-MasterPlanningUnderLegislativeandOrganizationalImpediments.pdf (accessed on 15 May 2020).

13. Balk, D.; Montgomery, M.R.; Engin, H.; Lin, N.; Major, E.; Jones, B. Urbanization in India: Population and Urban Classification Grids for 2011. Data 2019, 4, 35. [CrossRef]

14. Bartholomew, K. Integrating Land Use Issues into Transportation Planning: Scenario Planning. Utah. 2005. Available online: https://collections.lib.utah.edu/ark:/87278/s6qv44kf (accessed on 15 May 2020).

15. Bartholomew, K. Land Use-Transportation Scenario Planning: Promise and Reality. Transportation 2007, 34, 397-412. [CrossRef]

16. Bishop, I.; Pettit, C.; Van, B.; Lynch, J. Visualising What If? Generated Land Use Planning Scenarios. In Proceedings of the 11th International Conference on Computers in Urban Planning and Urban Management (CUPUM), Hong Kong, China, 16-18 June 2009; Hong Kong University Press: Hong Kong, China. Available online: http://www.dupad.hku.hk/cupumhk/ (accessed on 15 May 2020).

17. Brail, R.K.; Richard, E.K. Planning Support Systems for Cities and Regions; Lincoln Institute of Land Policy: Cambridge, UK, 2008.

18. Butt, W.A. An Evaluation of Outline Development Plan with Special Reference to Gujranwala Division. Master's Thesis, University of Engineering and Technology, Lahore, Pakistan, 1991.

19. Buxton, M.; Alvarez, A.; Butt, A.; Farrell, S.; Densley, L.; Pelikan, M.; O'neill, D. Scenario Planning for Melbourne's Peri-Urban Region; RMIT University: Melbourne, Australia, 2011. 
20. Chakraborty, A.; McMillan, A. Scenario Planning for Urban Planners: Toward a Practitioner's Guide. J. Am. Plan. Assoc. 2015, 81, 1-12. [CrossRef]

21. Chermack, T.J.; Lynham, S.A.; Ruona, W.E. A Review of Scenario Planning Literature. Futures Res. Q. 2001, 17, 7-32.

22. Ergen, Y. An Overview of Urban and Regional Planning; Ergen, Y.B., Ed.; IntechOpen: London, UK, 2018.

23. Eurostat. Urban Europe-Statistics on Cities, Towns and Suburbs; Eurostat: Luxembourg, 2016. [CrossRef]

24. Freitas, H.; Moscarola, J.; Jenkins, M. Content and Lexical Analysis: A Qualitative Practical Application. ISRC 1998, 35, 070498.

25. Futrell, J. Summer Scenarios: Educational Webinar Series. 2018. Available online: http://www. scenarioplanning.io/summer-scenarios/ (accessed on 15 May 2020).

26. Futrell, J. How to Design Your Scenario Planning Process, No. July/August. 2019. Available online: https://planning-org-uploaded-media.s3.amazonaws.com/publication/download_pdf/PASMEMO-201907-08.pdf (accessed on 15 May 2020).

27. Geertman, S.; Ferreira, J.J.; Goodspeed, R.; Stillwell, J. (Eds.) Planning Support Systems and Smart Cities; Springer International Publishing: Kam, Switzerland, 2015.

28. Geertman, S.; John, S. (Eds.) Planning Support Systems in Practice; Springer: Heidelberg, Germany, 2003.

29. Godet, M.; Fabrice, R. Creating the Future: The Use and Misuse of Scenarios. Long Range Plan. 1996, 29, 164-171. [CrossRef]

30. Goodspeed, R. Scenario Planning Course Development Guide; Lincoln Institute of Land Policy: Cambridge, MA, USA, 2015.

31. Goodspeed, R. An Evaluation Framework for the Use of Scenarios in Urban Planning; Working paper: WP17RG1; Lincoln Institute of Land Policy: Cambridge, MA, USA, 2017.

32. Goodspeed, R. Scenario Planning for Cities and Regions Managing and Envisioning Uncertain Futures; Lincoln Institute of Land Policy: Cambridge, MA, USA, 2020; Available online: https://cup.columbia.edu/book/a/ 9781558444003 (accessed on 15 May 2020).

33. GoP. 6th Population and Housing Census 2017 (Provisional Results). 2018a. Islamabad: Pakistan Bureau of Statistics. Available online: http://www.pbs.gov.pk/sites/default/files//Population_Census_2017_Results_0. pdf (accessed on 15 May 2020).

34. GoP. Punjab Cities Growth Atlas 1995-2015. Lahore. 2018. Available online: http://uu.urbanunit.gov.pk/ enewsletters/urbanatlas/index.html\#p=1 (accessed on 15 May 2020).

35. GOP, MOCC. National Report of Pakistan for HABITAT III. Islamabad. 2015. Available online: http: //habitat3.org/wp-content/uploads/Pakistan-Final-in-English.pdf (accessed on 15 May 2020).

36. Hameed, R.; Obaidullah, N. Challenges of Implementing Urban Master Plans: The Lahore Experience. Int. J. Soc. Behav. Educ. Econ. Bus. Ind. Eng. 2008, 2, 1297-1304. Available online: http://citeseerx.ist.psu.edu/ viewdoc/download?doi=10.1.1.307.7582\&rep=rep1\&type=pdf (accessed on 15 May 2020).

37. Hameed, R.; Nadeem, O. Punjab Land Use Classification, Reclassification and Redevelopment Rules: A Predicament or New Approach to Urban Management. Ali 2011, 4, 67-76.

38. Holway, J.; Gabbe, C.J.; Hebbert, F.; Lally, J.; Matthews, R.; Quay, R. Opening Access to Scenario Planning Tools. Policy Focus Report. 2012. Available online: https://www.lincolninst.edu/pubs/2027_Opening-Accessto-Scenario-Planning-Tools (accessed on 15 May 2020).

39. Hopkins, L.D.; Marisa, A.Z. (Eds.) Engaging the Future; Forecasts, Scenarios, Plans and Projects; Lincoln Institute of Land Policy: Cambridge, MA, USA, 2007; Available online: https://www.lincolninst.edu/publications/ books/engaging-future (accessed on 15 May 2020).

40. Hubacek, K.; Laixiang, S. A Scenario Analysis of China's Land Use and Land Cover Change: Incorporating Biophysical Information into Input-Output Modeling. Struct. Chang. Econ. Dyn. 2001, 12, 367-397. [CrossRef]

41. Huss, W.R.; Edward, J.H. Scenario Planning-What Style Should You Use? Long Range Plan. 1987, 20 , 21-29. [CrossRef]

42. Hussnain, M.Q. A Study on the Utilization of Information and Communication Technology in Preparation and Implementation of Development Plans: A Case Study of Rawalpindi. Master's Thesis, University of Engineering and Technology, Lahore, Pakistan, 2013. 
43. Hussnain, M.Q.; Anjum, G.A.; Wakil, K.; Tharanga, P.H.T.D. Improving Efficiency in Data Collection for Urban Development Plans through Information and Communication Technology. In International Conference on Town Planning and Urban Management (ICTPUM); Anjum, G.A., Ed.; University of Engineering and Technology: Lahore, Pakistan, 2014.

44. Hussnain, M.Q.; Waheed, A.; Anjum, G.A.; Naeem, M.A.; Hussain, E.; Wakil, K.; Pettit, C.J. A Framework to Bridge Digital Planning Tools' Utilization Gap in Peri-Urban Spatial Planning; Lessons from Pakistan. Comput. Environ. Urban Syst. 2020, 80, 101451. [CrossRef]

45. Hussnain, M.Q.; Waheed, A.; Wakil, K.; Tahir, A.; Pettit, C.; Pelizaro, C.; Jabbar, J.A. A Planning Support System to Aid Spatial Planning in Pakistan. In Proceedings of the 15th International Conference on Computers in Urban Planning and Urban Management (CUPUM2017), Adelaide, Australia, 11-14 July 2017; University of South Australia: Adelaide, Australia, 2017.

46. Hussnain, M.Q.; Khydija, W.; Abdul, W.; Ali, T. A Planning Support System to Optimize Approval of Private Housing Development Projects. IOP Conf. Ser. Earth Environ. Sci. 2016, 37, 012050. [CrossRef]

47. Hussnain, M.Q.; Waheed, A.; Anjum, G.A.; Naeem, M.A.; Tahir, A.; Pettit, C.; Hussain, E. Application of the Online WhatIf? Planning Support System in Peri-Urban Spatial Planning; Case Study of Muzaffargarh, Pakistan. In Proceedings of the 24th International Conference on Urban Planning and Regional Development in the Information Society 2019, Karlsruhe, Germany, 2-4 April 2019; Volume 4, pp. 77-87.

48. Jan, B.; Mohammad, I.I. Urbanization Trend and Urban Population Projections of Pakistan Using Weighted Approach. Sarhad J. Agric. 2008, 24, 173-180. Available online: http://www.aup.edu.pk/sj_ pdf/Urbanizationtrendandrbanpopulationprojectionsofpakis.DOC.pdf (accessed on 15 May 2020).

49. Kahila, M.; Marketta, K. SoftGIS as a Bridge-Builder in Collaborative Urban Planning; Springer: Dordrecht, The Netherlands, 2009.

50. Kahn, H.; Wiener, J.A. The Next Thirty-Three Years: A Framework for Speculation. Daedalus 1967, 96, 705-732.

51. Khakee, A. Scenario Construction for Urban Planning. Omega 1991, 19, 459-469. [CrossRef]

52. Kim, Y.M.; Bang, J.; Hyeon, S.K. A Planning Support System as a Tool for Sustainable Urban Planning. In Proceedings REAL CORP 2012; Manfred, S., Vasily, V.P., Peter, Z., Pietro, E., Eds.; Real Corp: Schwechat, Austria, 2012; pp. 1111-1119.

53. Klosterman, R.E.; Christopher, J.P. An Update on Planning Support Systems. Environ. Plan. B Plan. Des. 2005, 32, 477-484. [CrossRef]

54. Lazarean, A. OREGON Scenario Planning Guidelines 1 (April). 2013. Available online: https://frego.com/blog/ 2015/1/6/oregon-scenario-planning-guidelines (accessed on 15 May 2020).

55. Van Leeuwen, J.P.; Timmermans, H.J.P. Innovations in Design and Desision Support Systems in Architecture and Urban Planning; Van Leeuwen, J.P., Timmermans, H.J.P., Eds.; Springer: Dordrecht, The Netherlands, 2006.

56. LILP. Consortium for Scenario Planning. 2018. Available online: http://www.scenarioplanning.io/ (accessed on 12 December 2018).

57. Lock, O.; Bednarz, T.; Leao, S.Z.; Pettit, C. A Review and Reframing of Participatory Urban Dashboards. In City, Culture and Society; Elsevier Ltd.: Amsterdam, The Netherlands, 2020. [CrossRef]

58. Millett, S.M. How Scenarios Trigger Strategic Thinking. Long Range Plan. 1988, 21, 61-68. [CrossRef]

59. Mirza, M.I. A Review of the Master Plan for Karachi Metropolitan Region. In National Seminar on Planning for Urban Development in the Developing Countries with Special Reference to Pakista; Vanguard Books: Lahore, Pakistan, 1978.

60. Myers, D.; Alicia, K. Constructing the Future in Planning: A Survey of Theories and Tools. J. Plan. Educ. Res. 2000, 19, 221-231. [CrossRef]

61. Nadin, V. The Emergence of the Spatial Planning Approach in England. Plan. Pract. Res. 2007, $22,43-62$. [CrossRef]

62. Nasir, J.; Khan, M. Redefining Urban; A Case for Multi-Criteria Definition of Urban Areas in Pakistan. In 2 Urban; The Urban Unit: Lahore, Pakistan, 2018. [CrossRef]

63. Nazri, A.; Muhamad, L.; Ahris, Y. Scenario-Based Spatial Modeling for Land Use Planning and Evaluation. Conf. Map Malays. 2006, 3, 4-5.

64. Okeke, D. Spatial Planning as Basis for Guiding Sustainable Land Use Management. WIT Trans. State Art Sci. Eng. 2015, 86, 153-183. 
65. Owens, S. From 'predict and Provide' to 'Predict and Prevent'? Pricing and Planning in Transport Policy. Transp. Policy 1995, 2, 43-49. [CrossRef]

66. Paresi, M.; Michelle, M.; Alice, S.; Thomas, K. Atlas of the Human Planet 2016: Mapping Human Presence on Earth with the Global Human Settlement Layer. 2016. Available online: https://ghsl.jrc.ec.europa.eu/ atlas2016Overview.php (accessed on 15 May 2020). [CrossRef]

67. Patel, M.; Kasper, K.; Dale, S.R. Participatory Scenario Construction in Land Use Analysis: An Insight into the Experiences Created by Stakeholder Involvement in the Northern Mediterranean. Land Use Policy 2007, 24, 546-561. [CrossRef]

68. Payne, G. Best Practices for Spatial Planning and Development Control in Developing Countries. In International Conference on Land Policy; Arcadis Euroconsult: Jakarta, Indonesia, 2000; Volume 26, Available online: https://www.ucl.ac.uk/dpu-projects/drivers_urb_change/urb_infrastructure/pdf_city_ planning/Payne2000_BestPractices_Spatial_Planning.pdf (accessed on 15 May 2020).

69. Pettit, C.J.; Hawken, S.; Ticzon, C. Sydney Geodesign Workshop 2016: Developing a Framework for Collaborative Multi-Agency Scenario Planning; City Futures Research Centre, Faculty of Built Environment, UNSW: Sydney, Australia, 2017. [CrossRef]

70. Pettit, C.; Pullar, D.; Stimson, R. An Integrated Multi-Scaled Decision Support Framework Used in the Formulation and Evaluation of Land-Use Planning Scenarios for the Growth of Hervey Bay. 2002. Available online: http://www.iemss.org/iemss2002/proceedings/pdf/volumeuno/216_pettit.pdf (accessed on 15 May 2020).

71. Pettit, C.; Pullar, D.V. Towards Incorporating Dynamic Consequences into Regional Planning Scenarios. In AURISA 2000 Conference Proceedings; Roach, C., Ed.; AURISA: Hyatt Regency Coolum, Queensland, Australia, 2000.

72. Pettit, C.; Bakelmun, A.; Lieske, S.N.; Glackin, S.; Thomson, G.; Shearer, H.; Dia, H.; Newman, P. Planning Support Systems for Smart Cities. City Cult. Soc. 2018, 12, 13-24. [CrossRef]

73. Pettit, C.J.; Klosterman, R.E.; Nino-Ruiz, M.; Widjaja, I.; Russo, P.; Tomko, M.; Robert, S. The Online What If? Planning Support System. In Planning Support Systems for Sustainable Urban Development; Springer: Berlin, Germang, 2013; Volume 195, pp. 107-125. [CrossRef]

74. Pettit, C.J. Formulating a Sustainable Development Land Use Scenario Using GIS. ArcNews 2002, 24, 16. Available online: https://www.esri.com/news/arcnews/fallo2articles/formulating-sustainable.html (accessed on 15 May 2020).

75. Pettit, C.; Keysers, J.; Bishop, I.; Klosterman, R. Applying the What If? Planning Support System for Better Understanding Urban Fringe Growth. In Landscape Analysis and Visualisation: Spatial Models for Natural Resource Management and Planning; Pettit, C., Cartwright, W., Bishop, I., Lowell, K., Pullar, D., Duncan, D., Eds.; Springer: Berlin/Heidelberg, Germany, 2008; pp. 435-454.

76. Pettit, C.J.; Klosterman, R.E.; Delaney, P.; Whitehead, A.L.; Kujala, H.; Bromage, A.; Nino-Ruiz, M. The Online What If? Planning Support System: A Land Suitability Application in Western Australia. Appl. Spat. Anal. Policy 2015, 8, 93-112. [CrossRef]

77. Pettit, C.; Biermann, S.; Pelizaro, C.; Bakelmun, A. A Data-Driven Approach to Exploring Future Land Use and Transport Scenarios: The Online What If? Tool. J. Urban Technol. 2020, 0732, 20-44. [CrossRef]

78. Pettit, C.J.; Ray, W. A Planning Support System Toolkit Approach for Formulating and Evaluating Land-Use Change Scenarios. In Planning Support Systems Best Practice and New Methods; Geertman, S., Stillwell, J., Eds.; Springer: Dordrecht, The Netherlands, 2009; pp. 137-157. [CrossRef]

79. Pettit, C.; David, P. Planning Scenarios for the Growth of Hervey Bay. 2001. Available online: http: //www.geocomputation.org/2001/papers/pettit.pdf (accessed on 15 May 2020).

80. Pettit, C.; Pullar, D. A Way Forward for Land-Use Planning to Achieve Policy Goals by Using Spatial Modelling Scenarios. Environ. Plan. B Plan. Des. 2004, 31, 213-233. [CrossRef]

81. Pettit, C.; Tung-Kai, S.; Robert, S. An On-Line Planning Support System to Evaluate Urban and Regional Planning Scenarios. In Planning Support Systems in Practice. Advances in Spatial Science; Stan, G., John, S., Eds.; Springer: Berlin/Heidelberg, Germany, 2003.

82. Prieler, S.; Andrés, P.L.; Stefan, A. Three Scenarios for Land-Use Change: A Case Study in Central Europe. Central Europe. 1998. Available online: http://pure.iiasa.ac.at/id/eprint/5449/ (accessed on 15 May 2020).

83. Qadeer, M.A. Lahore: Urban Development in the Third World; Vanguard Books: Lahore, Pakistan, 1983. 
84. Roberts, E.J. Exploratory Scenario Planning: Lessons Learned in the Field; Working paper: WP14ER1; Lincoln Institute of Land Policy: Cambridge, MA, USA, 2014.

85. Russo, P.; Rosa, L.; Maria, F.C.; Christopher, J.P. Adoption and Use of Software in Land Use Planning Practice: A Multiple-Country Study. Int. J. Hum. Comput. Interact. 2018, 34, 57-72. [CrossRef]

86. Schoemaker, P.J.H. Scenario Planning: A Tool for Strategic Thinking. Long Range Plan. 1995, $28,117$. [CrossRef]

87. Stojanovic, M.; Petar, M.; Mihailo, M. The Scenario Method in Urban Planning. Facta Univ. Ser. Archit. Civ. Eng. 2014, 12, 81-95. [CrossRef]

88. Taylor, N. Commentary: What Is This Thing Called Spatial Planning? An Analysis of the British Government's View. Town Plan. Rev. 2010, 81, 193-208. [CrossRef]

89. Timmermans, H. Decision Support Systems in Urban Planning and Urban Design. Environ. Plan. B Plan. Des. 1994, 21. [CrossRef]

90. United Nations. World Urbanization Prospects: The 2014 Revision; United Nations: New York, NY, USA, 2014. [CrossRef]

91. United Nations. The World's Cities in 2018-Data Booklet. Available online: https://www.un.org/en/ development/desa/population/publications/databooklet/index.asp (accessed on 15 May 2020).

92. United Nations. World Urbanization Prospects: The 2018 Revision. United Nations Department of Economic and Social Affairs. 2018. Available online: https://population.un.org/wup/Publications/ (accessed on 15 May 2020).

93. USCB. 2010 Census Urban and Rural Classification and Urban Area Criteria. 2012. Available online: https://www.census.gov/programs-surveys/geography/guidance/geo-areas/urban-rural/2010-urbanrural.html (accessed on 15 May 2020).

94. Vitriani. Developing a Scenario Development Approach and the Alternative Land Use Scenarios: The Case of Pakal, Benowo, and Sambikerep Districts of Surabaya City. Ph.D. Thesis, University of Twente, Enschede, The Netherlands, 2010.

95. Volkery, A.; Ribeiro, T.; Henrichs, T.; Hoogeveen, Y. Your Vision or My Model? Lessons from Participatory Land Use Scenario Development on a European Scale. Syst. Pract. Action Res. 2008, 21, 459-477. [CrossRef]

96. Waddell, P. Integrated Land Use and Transportation Planning and Modeling: Addressing Challenges in Research and Practice. Transp. Rev. 2011, 31, 209-229. [CrossRef]

97. Walz, A.; Lardelli, C.; Behrendt, H.; Grêt-Regamey, A.; Lundström, C.; Kytzia, S.; Bebi, P. Participatory Scenario Analysis for Integrated Regional Modelling. Landsc. Urban Plan. 2007, 81, 114-131. [CrossRef]

98. Wibbeling, P. The Scenario-Planning-Process with the Peri-Urban Region of Rostock; HafenCity University: Hamburg, Germany, 2012; pp. 1-22. Available online: https:/www.ecologic.eu/sites/files/presentation/2013/ wibbeling_052012.pdf (accessed on 15 May 2020).

99. Xiang, W.N.; Clarke, K.C. The Use of Scenarios in Land-Use Planning. Environ. Plan. B Plan. Des. 2003, 30, 885-909. [CrossRef]

100. Yeh, A.G.O. Urban Planning and GIS. Geogr. Inf. Syst. 1990, 2, 877-888.

101. Zegras, C.; Sussman, J.; Conklin, C. Scenario Planning for Strategic Regional Transportation Planning. J. Urban Plan. Dev. 2004, 130, 2-13. [CrossRef]

(C) 2020 by the authors. Licensee MDPI, Basel, Switzerland. This article is an open access article distributed under the terms and conditions of the Creative Commons Attribution (CC BY) license (http://creativecommons.org/licenses/by/4.0/). 